\title{
THIN SECTIONING AND SURFACE REPLICATION OF ICE AT LOW TEMPERATURE
}

\author{
By Margaret A. Daley and Stephen H. Kirby \\ (U.S. Geological Survey, 345 Middlefield Road, Menlo Park, California 94025, U.S.A.)
}

\begin{abstract}
We have developed a new technique for making thin sections and surface replicas of ice at temperatures well below $273 \mathrm{~K}$. Cyanoacrylate glue forms a strong bond with ice and glass at $245 \mathrm{~K}$, eliminating the need to fix the sample to the thin-section slide by melting and freezing. Surface replicas are made by melting away sample material once the glue has cured Glue replicas are permanent and highly detailed, making them suitable for microstructural and textural studies at room temperature. Thin sections glued with cyanoacrylate glue are comparable in quality to melted-on sections. The ability to make thin sections without melting sample material is important in textural and microstructural studies of ice deformed at low temperatures because of annealing effects we have observed during conventional section making.
\end{abstract}

RÉsumé. Fines lames el répliques de surface de glace à basse température. Nous avons développé une technique nouvelle de réalisation de fines lames et de répliques de surface pour la glace à des températures bien inférieures à $273 \mathrm{~K}$. Une colle au cyanoacrylate forme un lien résistant avec la glace et le verre à $245 \mathrm{~K}$, éliminant l'obligation de fixer l'échantillon à la lame par fusion et regel. Les répliques de surface sont réalisées en fondant l'échantillon une fois que la colle a durci. Les répliques de colle sont définitives et fortement détaillées, les rendant adaptées pour des études de microstructures et textures à la température ambiante. Des lames collées au

\section{IN TRODUCTION}

Given the interest in the histories of the icy satellites of the outer planets, there is a need for experimental studies of the physical properties of ice at low temperatures and high pressures. Experimental samples deformed under these conditions, unlike natural glacial samples, are commonly far from their test conditions when sectioned and studied under cold-room conditions. Making thin sections of such samples without altering their structures and textures by annealing is a problem we encountered in conjunction with a study by Durham and others (1984) of polycrystalline ice deformed at low temperature and high pressure. In an effort to minimize textural changes during sectioning we developed a low-temperature sectioning technique that requires no melting of sample material.

The standard technique for making ice thin sections relies upon melting and refreezing a microtomed or melted surface to a thin-section slide (Langway, 1958; Rigsby, 1951, 1960). Using our technique, we make thin sections using chilled cyanoacrylate glue to fix a microtomed sample to the thin-section slide without warming and melting the sample surface. This enables us to make thin sections at $245 \pm 2 \mathrm{~K}$, the range of temperatures at which we maintain our cold room. Not only is cyanoacrylate glue effective as a bonding agent at low temperature (at least as low as $243 \mathrm{~K}$ ), but it also produces a highly detailed replica of the sample surface if the sample material is melted away after the glue has set.

\section{EXPERIMENTAL TECHNIQUE}

Thin-section making

Samples are cut to thin-section size with a band saw in a cold room maintained at $245 \mathrm{~K}$. The sawed surface is microtomed to produce a smooth surface. The cyanoacrylate sont comparables en qualité à celles collées par fusion. La possibilité de réaliser de fines lames sans fonte du matériau de l'échantillon est important dans les études de texture et microstructure de la glace déformèe à basse température à cause des effets d'anneau observés avec la technique conventionnelle des lames minces.

Zusammenfassung. Dünnschleifen und Oberfächennachbildung von Eis bei tiefen Temperaturen. Wir haben eine neue Technik für die Herstellung von Dünnschliffen und Oberflächennachbildungen von Eis bei Temperaturen weit unter $273 \mathrm{~K}$ entwickelt. Cyanocrylat-Leim bildet eine starke Verbindung zwischen Eis und Glas bei $245 \mathrm{~K}$, womit die Befestigung der Proben auf den Dünnschliffblättchen durch Schmelzen und Gefrieren vermieden werden kann. Oberflächennachbildungen werden durch Wegschmelzen von Probenmaterial nach dem Trocknen des Leims hergestellt Leim-Nachbildungen sind dauerhaft und sehr detailreich, womit sie sich für mikrostrukturelle und texturale Untersuchungen bei Zimmertemperatur eignen. Mit Cyanocrylate-Leim geklebte Dünnschliffe sind in ihrer Qualität mit angeschmolzenen Schliffen vergleichbar. Die Möglichkeit zur Herstellung von Dünnschliffen ohne Schmelzen von Probenmaterial ist wichtig für texturale und mikrostrukturelle Untersuchungen von Eis, das bei tiefen Temperaturen deformiert wurde, wegen der aufhebenden Wirkungen, die wir bei der üblichen Dünnschliffherstellung beobachten konnten.

microtome we use has a cryostat unit that maintains the temperature at $245 \pm 2 \mathrm{~K}$.

The sample is glued to a glass slide with cyanoacrylate glue that has been chilled to $245 \mathrm{~K}$. Cyanoacrylate glue remains liquid at $245 \mathrm{~K}$ when stored in a closed bottle although it is slightly more viscous than at room temperature. Common cyanoacrylate glue set slowly or not at all at $245 \mathrm{~K}$. However, low-viscosity cyanoacrylate glue sets in 4 to $5 \mathrm{~d}$ at $245 \mathrm{~K}$. Glue accelerators are available that cure glue almost instantly, but we do not use accelerators because they can turn glue cloudy, possibly by introducing tiny gas bubbles.

After the sample has been glued to the slide, the excess sample material is removed with a microtome until the sample is of the desired thickness, about $250 \mu \mathrm{m}$. After the section has been thinned, a cover slide is applied with cyanoacrylate glue. The cover slip prevents sublimation from the surface and reduces light scattering at surface irregularities. The excess glue around the edges seals the section. The refractive index of cured cyanoacrylate glue is $n=1.45 \pm$ 0.04 , compared to $n=1.5$ for glass and $n=1.31$ for ice, making it a suitable coating for optical studies.

\section{Surface replication}

A surface replica is made by preparing a smooth surface on the sample, etching the surface under vacuum to accentuate grain boundaries, and then gluing the prepared surface to a thin-section slide.

The smooth surface may be prepared either by microtoming or microtoming followed by melting. If a microtomed surface is melted to a glass slide and then removed by flexing the glass slide, the resulting surface is extremely smooth. However, an adequate surface can be made by microtoming alone.

After the surface is prepared, the sample is placed in a chamber under a vacuum of approximately 0.93 bar for a few minutes. We have found that 1 to 


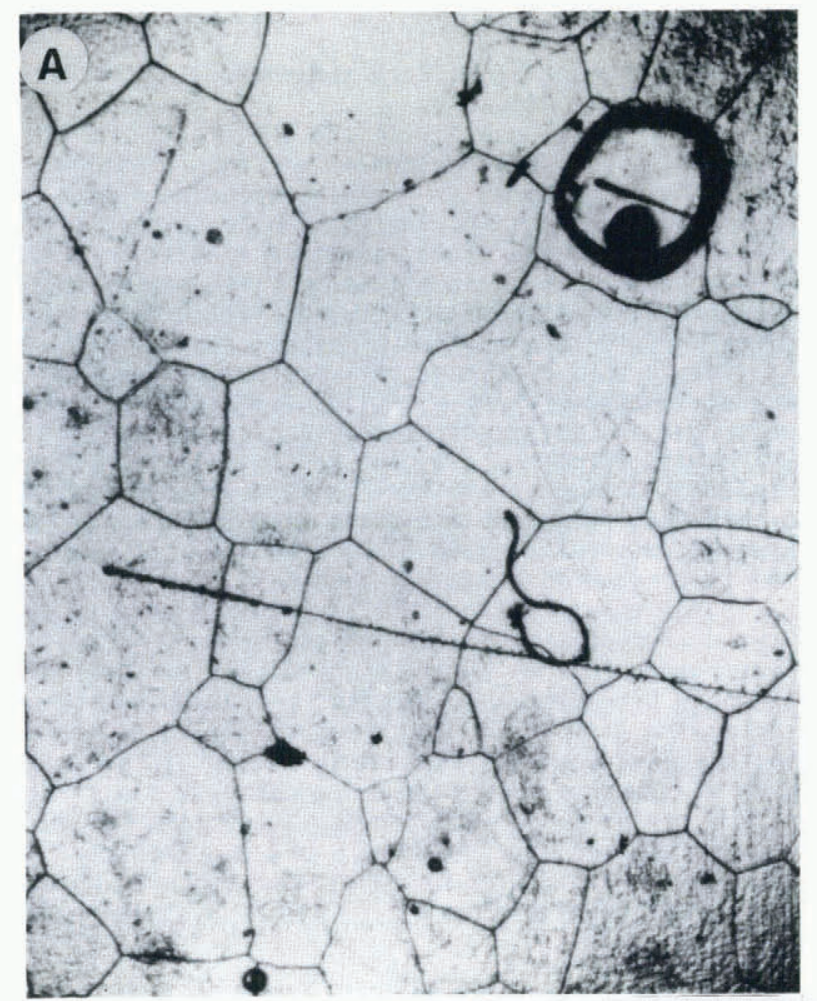

$\mathrm{O}$

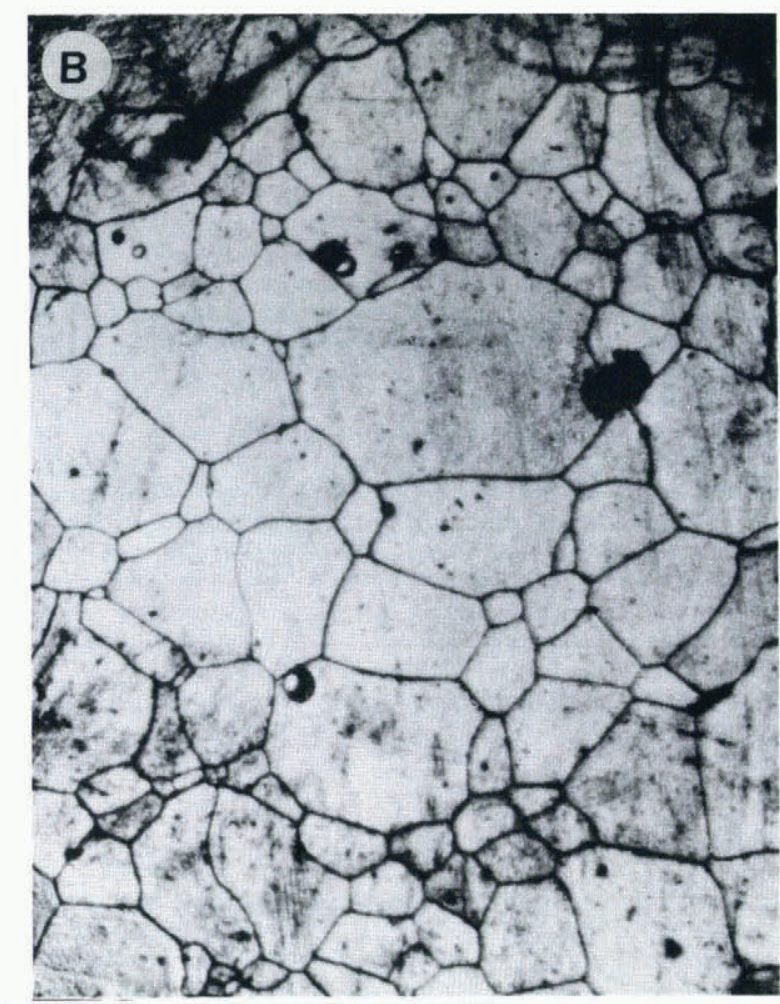

$4 \mathrm{~mm}$

Fig. 1. Photomicrographs of gold-palladium-coated replicas of starting material and of a deformed sample. Figure $1 \mathrm{~A}$ is a replica of the starting material. The dark circle in the top right-hand corner is a glue bubble. The other imperfections (a $2 \mathrm{~mm}$ fiber and the scratch near the middle of the figure) were probably introduced during sectioning. Notice the relatively straight grain boundaries and the well developed polygonal shape of the grains. Figure $1 B$ is a replica of a sample deformed at $50 \mathrm{MPa}$ and $244 \mathrm{~K}$. (Run no. 67 of Ducham and others (1983).) Notice the curvature of the grain boundaries and the increased amount of small grains.

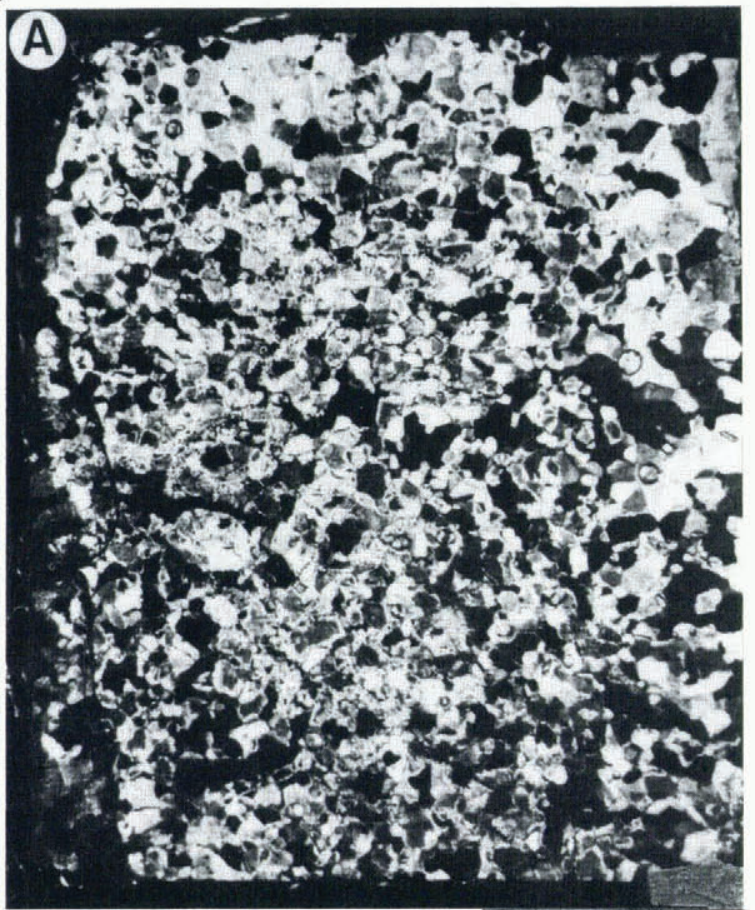

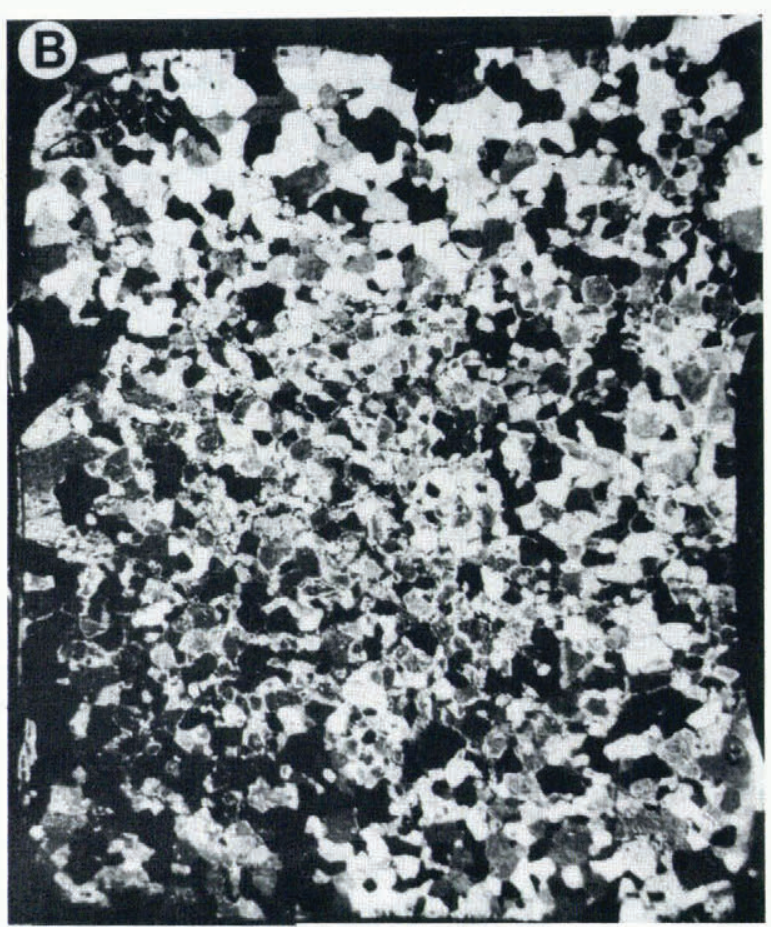

$2 \mathrm{~cm}$

Fig. 2. Photomicrographs of two thin sections of the same deformed sample ( $r$ un 24 of Durham and others (1983).: $P=120 \mathrm{MPa}, T=158 \mathrm{~K})$. Section $B$ was prepared by the contentional thin-section-making technique. The sample was melted and refrozen to the thin section slide. Section A was prepared by our thin-section-making technique. The sample was glued to the thin section slide with cyanoacrylate glue. crains are enlarged around the margins of section $B$, the melted section, whereas grain-size is uniform throughout section $A$, the glued section. 
5 min is the optimum time for selectively etching grain boundaries without producing excess surface topography within grains

The etched sample is next fixed to a glass slide with cyanoacrylate glue. It is important to use clean, dry slide as cyanoacrylate glue will replicate tiny bits of frost and dust at the glass-glue interface. The glue must set for 4 to $5 \mathrm{~d}$. There are glue accelerators available that cure cyanoacrylate glue rapidly and reproducibly in most environments, but as previously mentioned, accelerators tend to turn cured glue cloudy.

When the glue has cured the sample, material is melted away and the replicas are ready for viewing. For optimum resolution in reflected light replicas should be coated with a reflective material, such as gold-palladium or aluminum. This blocks out scattered light from the glue irregularities beneath the surface of the replica. However, if the quality of the replica is poor to begin with because of extraneous surface topography, coating may bring out more imperfections and further obscure textural features. (Figure 1 shows replicas of deformed and undeformed polycrystalline ice.)

\section{DISCUSSION}

Our goal in sectioning deformed sample material is to produce high-quality thin sections for detailed microtextural studies without changing the textures and features of deformation. We cannot exclude the possibility of significant annealing during sample storage at $245 \mathrm{~K}$. We did, however, look for changes during sectioning by comparing a melted-on section with a glued section of the same deformed sample. Grains are larger around the edges of the melted section than in the center (see Fig. 2), whereas grainsize in the glued section is uniform and comparable to the central area of the melted section. This indicates that grain growth occurred during meltsectioning that did not occur with our cold-gluing technique. This has important implications for samples that were deformed and extensively recrystallized at low temperatures The experimental conditions of such samples may produce high internal energy due to crystal defects such as dislocations and thus promote grain-boundary migration and grain growth when the sample is brought to melting temperature during conventional sectioning.

The technical quality of the glued sections is comparable to that of melted-on sections although microtome knife marks on glued sections do reduce their quality slightly. Replicas, because they are viewed in reflected light, are more sensitive to surface topography such as microtome knife marks. Consequently, replicas of microtomed flat surfaces are quite inferior to replicas of melted flat samples.

Unlike thin sections, replicas may be examined on any microscope without a cooling stage and they are permanent and easily stored. In fact, any section glued with cyanoacrylate glue has a built-in back-up replica, so that if the section is damaged or melted, a permanent record of the grain texture remains. We have already relied upon backup replicas for grain counts on some of our early sections.

Using cyanoacrylate glue as a bonding agent, we have developed a technique for sectioning and surface replication at $245 \mathrm{~K}$. We have seen textural differences between melted sections and glued sections indicating that grain growth occurs during the melting stage of standard sectioning but not in our coldgluing technique. Although we cannot be certain that we are preserving original deformation textures during storage and sectioning at $245 \mathrm{~K}$, we know that sectioning at $245 \mathrm{~K}$ prevents further textural changes that apparently develop at $273 \mathrm{~K}$ during standard sectioning.

\section{REFERENCES}

Durham, W.B., and others. 1983. Experimental deformation of polycrystalline $\mathrm{H}_{2} \mathrm{O}$ ice at high pressure and low temperature: preliminary results, by W.B. Durham, H.C. Heard, and S.H. Kirby. Joumal of Geophysical Research, Vol. 88, Supplement, p. B377-B392.

Langway, C.C., jr. 1958. Ice fabrics and the universal stage.U.S. Snow, Ice and Permafrost Research Establishment. Technical Report 62.

Rigsby, G.P. 1951. Crystal fabric studies on Emmons Glacier, Mount Ranier, Washington. Jowenal of Geology, Vol. 59, No. 6, p. 590-98.

Rigsby, G.P. 1960. Crystal orientation in glacier and in experimentally deformed ice. Jownal of Glaciology, Vol . 3, No. 27, p. 589-606. 